\title{
CHAOTIC IDENTITIES, LOVE AND FATHERING
}

\author{
Stephen Williams
}

\begin{abstract}
Fathers today are confronted with constantly changing ideas on their role as a parent. The old traditional forms of fathering i.e. the breadwinner and protector roles are being gradually replaced by a more reflexive role that places unconditional love from their children as a central theme in a new type of reflexive parenting. This article examines the role of fatherhood through the theoretical lens of reflexive modernity. It recognises that men are increasingly becoming dependant on their children for unconditional love and this is forcing men to become more involved in the lives of their own children. The theory of reflexive modernisation is applied to a group of 40 fathers from a post-industrial area of Britain to unravel the processes and practices being used in this "new" type of parenting. This research discovers that fathers in the 21 st century have numerous pressures from changing ideas about what is a good or bad father, but in the final instance it is their individualised responses to these societal and personal circumstances which create a new reflexive type of fathering. This type of fathering is therefore created by general social changes within a reflexive modern society and also by personal choice.
\end{abstract}

Key words: change, de-traditionalisation, fatherhood, love, reflexivity

In contemporary society we are confronted with such an array of conflicting social imagery that, as individuals, it is sometimes difficult to understand what is required in any particular role. This is why some academics argue that roles, duties and correspondingly social identities are becoming fragmented and diversified in the late modern age (Beck et al. 1994; Lupton \& Barclay 1997; Bauman 2000, 2001; Beck \& Beck-Gernsheim 2002). In all social areas the one-time universal formation of "modern" traditional certainties such as family, motherhood and fatherhood are now disparate and subverted (Doherty 1997; Silva \& Smart 1999). Traditional identities, traditional cultures and traditional institutions, such as the family, have become altered to an extent that they have become virtually unrecognisable from what preceded them. However, as with most sociological ideas this is a contested concept, especially when it is to do with notions such as gender, class or even masculinities as arguments rage as to whether such transformations can overcome rigid normative assumptions (Morgan 1996; Beynon 2002). Indeed, within the debates 
concerning the alteration of the institution of the family, particularly the roles played out within this social space, it is disputed whether the actual allocation of new duties to these gendered roles can overcome old rigid "norms".

To develop this into one research question, can the strength of the patriarchal gendered order with its normative assumptions resist social change? In fact, Michael Bittman et al. (2003) state that arguments concerning role changes within households, which are supposedly driven by what they call "exchange theory" with women expecting help with the household chores in exchange for bringing money into the household is questionable. They argue that this can be subverted by the normative ideologies behind gender with all its stereotypes. In other words, and to paraphrase the title of Bittman et al., role changes will eventually be trumped by monolithic stereotypes concerning gender "norms" and rather than a recreation of new roles we have a continuation with "normative" gender roles which will proceed infinitum. Indeed, when looking at traditional family roles such as fatherhood, Esther Dermott (2003) argues that while there may be a "demise of the breadwinning father" other changes are too difficult to detect (Dermott 2003: 1). Nevertheless if we as social scientists want to detect these changes we should look at the "new" individual relationship between father and child, rather than solely looking for changes in larger universal concepts such as gender roles, because these can themselves be vague and ambiguous. Individual changes in behaviour appear to be easier to detect than "structural" change. Slightly earlier David Morgan (1999) argued that the gendered order is maintained or dismantled with regard to what is done in practice around the household, and therefore looking at what men/fathers did "in practice" was the best indicator of any form of social change.

Drawing on these ideas and browsing through the catalogue of academic literature which is now being published on fatherhood, we find similar dilemmas and questions concerning these new roles (Hawkins \& Dollahite 1997; Dienhart 1998; Dermott 2003, 2008; Williams 2008). These are directly related to the following questions: What is a father? Is there more than one type of fatherhood? Has fathering changed and if it has changed what has caused this change? All are practically impossible to answer without a full understanding of the processes involved in shaping our lives in late modernity. To fully understand these processes this paper attempts to explain how fathering has become altered by being at the crossroads of conflict over societal and personal change. Using concepts like reflexive modernisation, individualisation, choice and determinism it shows that fathering is being altered by personal choices, partnership conflict and what is now accepted by society in general. This is not to say that fathers are simply choosing role models from an eclectic array of choices, but rather they are faced with a set of options which determine what 
and who they are. Indeed fatherhood today is like being at an all-you-can-eat restaurant, it may be a vast menu to choose from but there are parameters and therefore limitless choice is not an option. In other words, although it may appear that there may be limitless options to choose from, in a certain way these are still structurally formed. Therefore changing roles are never simply personal choice or a structural determinant but a combination of the two. This paper aims to explain changes in fathering through the lens of reflexive modernisation. It traces how fathers are slowly changing due to a struggle between personal relationships and society's structural alterations and hence in the process they are becoming reflexive fathers (Williams 2002, 2008). This is achieved through an analysis of reflexive modernisation, particularly Ulrich Beck and Elisabeth Beck-Gernsheim's interpretation of reflexivity with the main elements being reflection (choice) and reflex (structural change), and applying these theories to qualitative interviews carried out amongst a group of fathers.

\section{METHODS}

Semi-structured interviews were used to provide the research with a rich vein of information on individualised fathering. The interviews took place in the post-industrial South Wales valleys and the city of Cardiff. The fathers were asked to explain their lives as fathers and they did this with incredible frankness and warmth. The sample frame was made-up of 40 fathers evenly divided into four subsections to roughly represent the socio-economic spectrum of late modern life. Indeed, although the findings in this paper give us an in-depth understanding of this sample of fathers, more general observations on fatherhood could be misleading because of the small scale of the sample. However, these subsections were divided as follows:

1. Professional fathers

2. Employed fathers

3. Unemployed fathers

4. Student fathers

Professional fathers were categorised as working in a recognised profession, such as teachers and lecturers. The employed subsection included any father working in a non-professional job, and not included in any other subdivision. Unemployed fathers were the long-term unemployed who had been on benefits for more than six months. The student fathers were made-up of men who had left full-time employment and entered university as full-time students. All 
categories were needed to trace the chaotic formation of reflexive fathering in the 21 st century.

It has been argued that the relationship between parents and children is in the midst of change, as parental authority over children is becoming less authoritarian and more negotiated (Giddens 1990; Jamieson \& Toynbee 1990; Beck \& Beck-Gernsheim 2002; Williams \& Williams 2005). Indeed, research undertaken by a team at Lancaster University investigated the late modern view that families are becoming less authoritarian and more democratic. Jo Warin et al. (1999) investigated the parent-child relationship in relation to perceived ideas on the democratisation of family life and a demand, by government, for a reversal to more parental control and moral authority over young people. They concluded, in relation to fathering, that some fathers portrayed themselves as those who "discipline" whilst the mothers, on the other hand, "negotiated" and "talked" to their children. Conversely, they also argue that other fathers were frequently reluctant to act as disciplinarians and criticised government policy that made parental authority replicate increasingly outdated roles. In fact, they argue that policy makers need to listen to parents and draw on their experience, instead of making policies based on mythical idealised roles.

Gill Valentine (1999) argues that in today's society the dynamic between parents and children is fundamentally shifting. The parent and child relationship that was once enclosed by an authoritarian framework is increasingly becoming challenged by negotiation. Valentine asserts that children's spatial boundaries are beginning to be negotiated, as parents are becoming increasingly dependent on their child's localised knowledge. Included in these negotiations, is the child's social competence and their local knowledge that is no longer dependent on preconceived ideas of competence simply due to biological age. In this context, children are able to have an influence over their parents as they negotiate what they can do as well as where they can go (Williams \& Williams 2005). As Valentine puts it:

Rather, children actively challenge parental performance of authority. Often where parents' performances are weak and children's are strong, children can resist parental restrictions on their use of space and indeed often have a significant voice in household decisions. (Valentine 1999: 150)

This is linked in the work of Stephen Williams and Lynda Williams (2005) to the de-traditional processes at work in late modernity as the democratisation of all family relationships proceeds at a pace. Today's children are therefore influencing their spatial boundaries by developing a "new" negotiated relation- 
ship with their parents. Lynn Jamieson and Chris Toynbee (1990) had historically traced the decline of the authoritarian parent through the twentieth century. They believed that "it is probably true to say that many contemporary parents are closer to their children and treat them in a less authoritarian way than their own parents did. Indeed, there is a good deal of evidence supporting the claim that parents have become far more child-centred." (Jamieson \& Toynbee 1990: 108) Although in the last instance parents can still use their economic power and physical strength to demand their parental authority, this becomes increasingly difficult to justify in our late modern society.

It appears that it is no longer acceptable for traditional authoritarian roles, such as the patriarchal father, to demand the privileged position they once held in family relationships. In fact, it has become the "norm" for all participants in late modern relationships to demand their personal and emotional fulfilment within these new roles. It is also held, that marriage and kinship relationships can no longer survive based solely on traditional ascribed duties within familial roles. These "new" partnerships must provide individual love, emotional support and a sense of a united front against the world, as Beck and Beck-Gernsheim (1995) argue:

The sort of change evident in the marital relationship as society moved from pre-industrial to modern times is also apparent in the relationship between parents and child. In both, the common cause - the survival of the family unit - has disappeared; in both, the relationship between the persons involved is less economic and more personal and private, with all the hopes and interests this involves; in both, the relationship depends largely on the growing, not to say hypertrophic emotional needs of all parties in an individualised world (including all the rewards and horrors inherent in intense feelings). (Beck \& Beck-Gernsheim 1995: 105-106)

Thus, the emphasis on what some describe as the pure relationship (Giddens 1992; Jamieson 1999) has shifted, in these terms, from failed relationships of marriage and adult love towards the unconditional love between parent and child. The child is becoming the object of unconditional love, as individuals seek to develop a continual, constant and unfailing emotional love in their increasingly fragmented and unstable lives. The relationship with your children appears to be the only way parents can "guarantee" a source of love that will not fail, as their other relationships appear to be constantly failing. Anthony Giddens (1992) has pointed out that this relationship is no longer authoritarian as negotiation and compromise are all included in this new partnership. In fact, Beck \& Beck-Gernsheim (1995) argue that adults now express all their 
emotional fulfilment through their children, and thus invest their emotional as well as financial capital in their offspring. Children have become an investment and expensive commodity for the expression of unconditional love. To fully understand these social changes as well as detect the complex and sometimes contradictory nature of reflexive fathering, we must now take a brief look at reflexive modernity itself.

\section{REFLEXIVE MODERNITY? DECISIONS, NOT SIMPLY CHOICES}

Changes to traditional roles within the reflexive modern world mirror and are partly driven by, the speed of change in the communicative industries which helps to alter traditional social relationships (Castells 1999; Bauman 2000). Beck et al. (1994) and Beck-Gernsheim (1998) have each outlined these late modern processes and their complex social significance, particularly when looking at the recreation of new social roles such as reflexive fatherhood. Reflexive modernisation is quite simple in its basic concepts, although rather complicated in its resultant consequences. Reflexive modernity is the realisation that modernity has gone through two simple stages, a first "simple" phase of modernity and a second reflexive stage. Thus, within early modernity the public sphere aspired to be democratic and egalitarian, but the private sphere remained largely patriarchal, undemocratic and centred on the male's dominant economic position (the breadwinner). In real terms, this meant that women were in a subservient, ascribed position and were separated from the economic power that work provided. In the reflexive stage of modernity, however, the public and private spheres start to merge and the dominant economic position held by men begins to be eroded. As Anthony Giddens explains:

Modernity always set itself against tradition, but in many areas of life, tradition persisted particularly in everyday life. The reason was primarily the dominant position of patriarchal family, which remained un-democratized. That family form, together with the norms of gender and sexuality associated with it, is now breaking down creating both opportunities and dilemmas in its wake. (Giddens 1998: 118)

Subsequently, the family is becoming democratised by the de-traditional forces of reflexive modernisation. De-traditional ways of living are part of what Beck (1992) describes as the "individualisation" of all social and economic relations, and occur where the individual is forced to respond to the breaking up of the traditional order. Individualisation is therefore viewed as occurring in all areas of social life, as the individual becomes self-monitoring and reflexive. Thus, 
the main difference between postmodernity and reflexive modernity is that postmodernism rejects the idea of a narrative of progress, while reflexive modernity is a continuation of the modernisation process itself. In a way we have a dialectic process taking place, with the old thesis being challenged by a new antithesis and the resultant synthesis combining both the traditional and the new or non-traditional.

In this light new roles developed in reflexive modernisation could be seen as the unintended consequence of the dialectic of the enlightenment project, and thus as an outcome of a conflict between the traditional and the new in the modernisation process itself. Indeed, Zygmunt Bauman (2000) makes a similar argument when drawing an analogy between late modern forms of work and the increasing popularity of co-habitation as an alternative to marriage today. Bauman contends that:

The present-day "liquefied", "flowing", dispersed, scattered and deregulated version of modernity may not portend divorce and the final break of communication, but it does augur the advent of light, free-floating capitalism, marked by the disengagement and loosening of ties linking capital and labour. One may say that this fateful departure replicates the passage from marriage to "living together" with all its corollary attitudes and strategic consequences, including the assumption of the temporariness of co-habitation and the possibility that the association may be broken at any moment and for any reason, once the need or desire dries out. (Bauman 2000: 149)

In this excellent analogy, Bauman links the behaviour of global capitalism to the changing nature of relationships in postmodernity. In other words, in reflexive modernity it could be argued that the very transient nature of modern capitalism has a causal effect on the instability and changing character of late modern relationships. Consequently, globalisation has a profound impact on how we live, what we are and what we wish to be. Reflexive modernisation is therefore an explanatory tool in understanding the break-up of traditional roles, such as fathering, and their replacement by individualised fragmented "selfcreations", or what Giddens terms "self-monitoring". These "self-creations", however, are rather paradoxically not entirely due to personal "choices".

Essentially, reflexive modernisation holds that we as individuals have and must make decisions, but decisions peppered with a variety of personal experiences. Risk society has pushed modernity into reflexive modernity as the result of the unpredictability of all our actions. With regard to society, it is the side effects of the modernisation process that produce change. Change starts from the problems inherent in simple modernity, an example being environ- 
mental problems caused by industrialisation, and this is only revealed to individuals when modernisation produces unintended circumstances. Therefore, intrinsic motivations within the modernisation process have no certainties and progress is unforeseeable. Subsequently, we cannot predict where the flexible nature of global capitalism will direct us, and thus we cannot fully predict the outcome of these unconscious effects on institutions like the family. With regard to the family, we are witnessing changes that are the outcome of reflexive modernisation including the democratisation of family life, greater female participation in paid work and the increasing abandonment of traditional ways of life. One of the basic principles behind the concept of reflexive modernisation is the idea of a transition from traditional society to post-traditional society. Reflexive modernisation is the opposite of simple modernity, wherein positions or roles are entrenched in a rigid ordering. By contrast, today we can increasingly detect the promotion of the individual through self-monitoring and responses to situational necessity.

As with post-modernity, reflexivity is the central plank in reflexive modernisation, although the latter is marked by a different type of reflexivity. Thus, Beck (1994) emphasises reflexivity as having both an unintended element and a conscious element to change. This position has similarities to the earlier work of Giddens (1984) on structuration theory. Beck makes this point clear when he disagrees with Lash (1994) over the nature of reflexivity. His criticism of Lash is that he over-emphasises the postmodern notion of reflexivity, which stresses reflection or choice. It is this understanding of reflection and reflexivity that is central to this thesis, mainly because of a critique of the postmodern understanding of choice and cognitive "options". As Beck et al. argue:

Scott Lash distinguishes between cognitive, moral and aesthetic reflection. To that he connects the objections to Giddens and my own work, that we base our argumentation on a cognitively foreshortened understanding of reflection... This is accurate in one respect, simply because so far only Lash has worked out the indubitably important aesthetic dimension of reflexive modernisation. At the same time, however, this objection misses the central distinction between reflection (knowledge) and reflexivity (unintentional self-dissolution or self-endangerment) which is the basis of my argument. Putting it another way, it is precisely the distinction between cognitive, moral, and aesthetic dimensions of the reflexive modernisation which make it clear that Lash speaks exclusively of (more or less conscious) reflection, and misunderstands the problematic of unconscious, unintended reflexivity in the sense of selfapplication, self-dissolution and the self-endangerment of industrial modernisation. (Beck et al. 1994: 176) 
When applied to a social role such as fatherhood the dual composition inherent in reflexivity has two effects: conscious choice and decisions created by situational circumstances. So, when fathers become reflexive in their role as a male parent this is not entirely reliant on egalitarian personal attitudes or choices. The unconscious effects of modernity's self-endangerment and its unforeseen consequential side can also direct individuals to specific "limited options". The decisions made by fathers with regard to their role have an element of personal choice, but these are "choices" driven by household necessity. One of the major unintended consequences of modernity is a result of women going back to work, staying in employment or even deciding not to work at all. In this light, fathers have to respond to this situation, either positively or negatively, and the decisions they make have an effect on their own role as well as implications for their relationship.

Decisions in all areas of life reveal that social categories, even the ones which were once deemed biologically rigid such as gender and sexuality, are becoming contested in this de-traditionalised phase. As Beck explains:

The same thing can be observed and illustrated in the erosion of male and female roles. At first sight the argument sounds familiar: equality of women in the labour market is abolishing the familial foundation of industrial society. But that only means that the basis of the division of labour and its certitude is crumbling. Here the "classical" roles of men and women mix and subvert one another. That should not be equated with the displaced scenarios of wealth-risk conflict either. Instead it means loss of certainties, insecurity, deciding, negotiations and thus communication and reflection as well. (Beck 1992: 180)

Consequently, to determine the state of fatherhood today we must examine a vast array of decisions with which fathers are increasingly faced. These decisions are conflict driven as partners "fight" over who works, childcare arrangements, new negotiated relationships after divorce or separation and even who does what with regard to domestic responsibilities. Through all these arguments, new roles are driven by demands for justice, citizen's rights and a detraditional view on partnerships, marriage and work. All this is part of the individualisation process driven by risk society. Included within individualisation is the break-up of traditions, such as gender and tradition, as household lifestyles are becoming increasingly situational. Universalised provisions and categories are being replaced by an increase in situational decisions regarding the self, self-improvement and household circumstances.

The point that we must take from this theoretical discussion is that if these theorists are correct, we should be able to detect a shift towards a more affec- 
tionate father expressing the delight of being a parent. The biggest problem with this concept is that it is virtually impossible to quantify what exactly constitutes fatherhood. This problem is apparent in the earlier work on fathering by Charlie Lewis and Margaret O'Brien (1987). They argue that research on fatherhood has concentrated on fathers almost wholly within the workforce. In contrast, there has, historically, been a paucity of research on what fathers do in the home. This leaves us with a virtually impossible task of comparing today's fathers with earlier generations, because the literature lacks a historical base. Conversely, the fathers in this study always compared themselves with their own fathers, and appear to have both a set of traits attributed to the past fathering role as well as the new more reflexive role.

It seems that in earlier epochs, particularly in early modernity, traditional positions were not questioned and instead, were largely simply done. In late modernity fathers, mothers, children, grandparents and all kinship associations are developed on a one-to-one basis opened up by the reflexivity of institutions and structures. This idea is the basis behind the pure relationship and the reflexive as well as the self-monitoring principals of reflexive modernisation. The interviewed fathers are tacitly aware that they are doing something different and new, but they are also very concerned that they do not make a different set of mistakes.

These fathers have begun to change traditional fathering, as they are put under intense pressure from their changing family. They have all challenged traditional fatherhood in one way or another, either consciously or unconsciously, by their actions and deeds within family life. Virtually all the fathers interviewed expressed a delight in being a father and expressed a wish to be involved with their own children, something very different from the economic father presented by other research. They all considered themselves to be good fathers and wished to experience parenting in a more positive fashion than their own fathers. The exact meaning of male parenting involvement was individualised, and even discipline was up for negotiation within the father-child relationship. Simon, a deputy head-teacher, exemplifies this opinion when discussing discipline, arguing that he could not demand his children to be as obedient as he was. He asserts that one cannot place demands on today's children:

Simon: No, that's right you can't, you have got to negotiate. Again it starts when they are young and you have an open relationship. There are three types of fathers, parents, aren't there? You have got your authoritative and you've got your liberal. And I like to think I am between liberal and authoritative. 
Simon has two boys who are 15 and 17 years old, and explained that he wanted to be distinguished from an acquaintance. He recounted an experience of when an individual had told him that he needed to control his sons far better and he should not let them go alone into town. Simon believed that he could no longer dominate his children to do what he wanted. He argued that this was the case because they would not "take any notice" and negotiation was preferable, rather than not knowing where they were. For him, this exemplified a new "liberal" fathering approach.

Fathers were not only adapting to their children, but also reacting to what they felt to be "better" fathering. They drew upon mundane assumptions of good fathering, and compared that image with media panics about absent "bad" fathers. All these fathers talked about issues such as involvement and time with their children. This was fairly constant throughout the interviews, as the fathers spoke of increasing both their time spent and involvement with their children. Involvement ranged from the nurturing of children right through to the "usual" fathering activities of playing games. However, they did not see their individualised involvement on an equal basis with the partner, and sometimes appeared to be very traditional. Alan explained that his involvement was in one sense very traditional, as he was normally involved with their leisure time and homework. This type of involvement was expressed by a substantial number of the interviewees (over half), as Alan states:

Alan: It's probably with their leisure time like, when they are outside their school environment. But I spend a lot of time with them leisurewise, and obviously with their homework and things like that, normally after school.

Alan admits, however, like so many of the fathers, that his involvement and the time he spends with his family are limited by work commitments. Nevertheless, perhaps in contrast to previous fathering generations, he attempts to spend as much of his "spare" time with them. For an overwhelming majority of these fathers, "being involved" meant participating in all aspects of their children's lives and this was a recurrent theme. Individual interpretations of involvement also appeared to be reliant on other "factors". Categories and labels such as the good lone parent father and the bad absent father appear to be arbitrary, and dependent on individual circumstances. Mike, it could be argued is a good father, because he is presently a lone parent looking after his teenage daughter, and yet his involvement appeared dependent on the age of his daughter. However, when his daughter was a baby he could be described as an absent father. As Mike explains: 
Mike: Like I said, we split up two or three months after the birth. And then the mother looked after my daughter or her daughter for, I would say the first four years of her life, and I'd see her at first when she was little, I didn't use to see her that often. But when she got older and a little bit more independent then she didn't need her mother so much, I'd started having her on Sundays but then it moved to weekends.

Q: So why do you think that you never saw her that much in her first years?

Mike: I think first of all it would have to be something to do with me. Because, I mean, she is my daughter and it's up to me, it's not like my daughter can see me, I've got to make sure I see my daughter. But also I think you need that initial period when you've just broke up of separation so you can get your heads together and everything like, you know. So I would have to say it was my fault why I never saw her, but it is also the fact of you know I hadn't ever changed a nappy in my life and my daughter was getting breast fed ...

Mike's life history is complicated, however looking at his comments we can detect two separate issues. One was that the strong normative expectations of motherhood impinged on his sense of fathering, he felt that his daughter was too small and delicate for him to feed and nurture. The second issue must be how close both absent fathering and "new" fathering can be; this could negate the right wing talk of immorality amongst "absent" fathers and a separate underclass "culture".

There were also other types of involvement that appeared to depend on the age and gender of the children. When Graham discussed his involvement, age and perceived gender differences between sons and daughters were other considerations. This appeared to be suggesting that time was more important for his young daughter, whilst support and a chat was good enough for his older son. As Graham explains:

Graham: Yeah I always try to make time for them. I suppose that [daughter] at the moment is the one I spend most time with, generally she goes to bed early. When you go and try to have a chat with [son], it's like, oh dad I am one nil up, come on, get out (laughter). He is 13, he doesn't really want to know me.

Graham stated that his 13-year-old son "doesn't really want to know me", yet they connect in another more "traditional" masculine activity: football. Graham, like a lot of the fathers interviewed, wished to behave differently towards his children when compared with his own father's involvement with him. Early in the interview Graham argued that his father never took an interest in his 
football, and he has made sure that he has taken an interest and connection with his son's football. On the other hand time was of more importance for his daughter. This is an interesting mixture of modified traditional fathering with the son and a "new" type of created involvement with his daughter. As Graham explains:

Graham: Umm, well now, it's when I mostly get home from work. You know... umm... I just always made time for... who's the daughter, who is $4 \ldots$ umm... [son] is generally upstairs playing his computer or whatever they call it... umm ... But I can get along with him greatly. We have the same interests, the same music interests, which I never ever impressed upon him. He just happens to like the same... umm... The football he likes the same sides as me.

Involvement was a constant theme, although the precise meaning of involvement could sometimes be quite varied and ambiguous. What "involvement" meant for one father was different for another, individualising the exact meaning. Ivor, a father of one, saw reading and contributing in the nurturing side as involvement:

Ivor: Oh yeah I am involved with her as much as I can be really, and... umm... I do get involved in everything she does. Well I will try to help if she is reading, I help her read, I read her to sleep. I put her to sleep most of the time.

Warin et al. (1999) found that fathers get involved in ways other than the classical nurturing involvement related to the motherhood role, and have instead become engaged in areas, not looked at by a number of researchers, e.g., being the family "taxi-driver" with teenagers and "playmates" on the playstation. Unlike in the study by Warin et al. (1999), the fathers, interviewed in the course of the current research, did more, and wanted to do more, than just play with their offspring. Playing was not the only way these fathers involved themselves with their children. This group involved themselves in more traditional nurturing activities, although even here involvement was not exactly equitable. Dividing involvement on gender grounds seems to be quite common, and as we have already seen above, involvement also changes with the age of the children, as Dave explains:

Dave: With [his son], cos he is nine years old, I am more involved with him, when it comes to things like school work, playtime, playing, going out, things like that. With the twins, with the girls, they are twelve years old now and the girls umm... again I do some homework with them, but not much strangely enough. And going out they are becoming 
more independent and they rely upon us less for their entertainment and their social time.

Individual differences in the way these fathers become involved with their children are very distinct, and as with other areas in fathering individuals select their own type of involvement. Ivor, the motor mechanic father of one daughter exemplified this point very well when he explained his individual fathering style:

Ivor: Well, you know, we try and share things, we go out together, you know food, you know she's having a meal with us, cutting her food type sort of thing, talk to her, make sure she is content. If you're waiting for food in a restaurant or whatever, play with her when she is out.

Ivor showed a mixture of traditional and de-traditional fathering, playing and helping to feed her. The late modern father's relationship with his children is much more complicated than in previous generations. Although breadwinning is still central to the majority of these fathers' sense of self, they are developing or beginning to dabble in other areas of parenting. Prescribed traditional roles are being replaced by a greater amount of "voluntaristic" types of fathering created by greater choice or decisions.

In other words, changes in the labour market and the demands for citizen's rights by women are beginning to slowly change the position of, and demands on fathers. In the words of Beck \& Beck-Gernsheim (1995), fatherhood has become a consequence of individualisation, where expectations are not fixed in stony tradition and are developed by individual life styles. The point here is that fathers are no longer "just" breadwinners or "just" role-models but are pushed by circumstances to be something more than a singular one-sided icon. Feminists in the past have said that mothers had to be great chiefs, brilliant maids, Florence Nightingale nurses and wonderful lovers; well, to a certain extent its payback time as the same is now expected of the male. However, perhaps unfortunately, "wonder-man" has still not arrived and only a mere, at best, "blundering male" exists.

\section{BEING AT THE BIRTH}

The change in the lives of these men when becoming a father is considerable, and this clearly illustrates that fathers do more than just provide finance. Theodore Cohen (1993) reveals the impact of this change in a study that examines men before and after fatherhood. Fatherhood in Cohen's study was clearly not only an economic function, but also has an emotional element. This emo- 
tional involvement and willingness to be part of their children's lives was mostly exemplified by being at the birth. Virtually all the fathers expressed their opinion that the father should attend the birth, with very little reservation (only two had reservations about fathers being at the birth). Consequently, being at the birth seemed to serve a few general purposes in the experiences of these fathers. The first was an emotional release and a feeling of euphoria at the birth of their child after the long pregnancy. The others include a type of solidarity with their partners, sharing the emotional phenomenon, attempting to understand the pain involved in childbirth and bonding with the infant. The excitement and emotional fulfilment of being at the birth had traditionally been denied to men, but these fathers wanted more than just sitting outside in the waiting room.

Sometimes, however, even this can still be denied to a father, as traditional ideas prevail with individuals in the medical profession. As Richard, the taxi driver, explains: "I was there to do the fatherly bit and holding the wife's hand and this big hefty sister came out, pushed me out of the way and said if you're going to faint you'd better do it in the corner." These fathers gave the overwhelming impression that they very much enjoyed being at the birth for varying reasons. To Duke, the deputy head of a secondary school, this was his way of involving himself as much as he possible could with the birth and the arrival of a planned as well as much wanted first child.

Duke: Personally yes I wouldn't have missed it for the world, because umm... we wanted this baby a lot, it was our first baby anyway and we wanted it. We had been married three years by then, and we settled in, done the things that you do when you're first married, and we wanted this baby to come and I wanted to be there and be part of it. I enjoyed my wife's pregnancy if you see what I mean and when we look at the photos now of when we umm... you know taken just a few minutes after the baby was born, I don't know who looks more exhausted me or her.

This appeared to be a time when the acceptable emotionless hegemonic masculinity could be relaxed. Fathers were allowed to become sensitive and experience the 101 joys and emotions of becoming a parent. Steve replied in this fashion when asked how he felt during the birth of his children:

Steve: I was there and observed, watched and went through 101 different emotions. Other than that, and support and encouragement I don't really know how else I could have been involved.

Adjectives such as "emotional", "elation", "fantastic" were frequently used to express their feelings at becoming fathers and this type of experience was 
spread right across the survey. Peter and Graham are the best examples, and eloquently express the feelings that new fathers feel towards their children. Peter also believes that this emotional expression could not have been shown 20 years ago. We can view this change as illustrative of how the breaking up of the traditional dominant masculinity is allowing greater individual expression of the men's emotional selves (Connell 1995; Giddens 1992; Williams 1998). Childbirth for Graham, the industrial roofer, and Peter, the bank clerk, was a real emotional experience even though, in both cases, becoming a parent was not planned. The emotionally charged atmosphere of childbirth helped them bond with their children and also help them express their feelings, as they explain:

Graham: Just the sheer elation isn't it, it's fantastic, it's almost unreal. Well it is unreal, because you've never had to cope with those feelings before. You've got something there that's just, oh it's just fantastic. There is something there that's real, it's looking at you and it's just, you know, you have to do as much as you can for it for the rest of your life. You know that there and then, it's that inner warmth, it's that bond straight away.

Peter: I found it very emotional when [daughter] was born. I did shed a tear but uh... I think it's all down to the individual, if they're going to be emotional... about 20 years ago men were men and didn't show any emotions. I think the last 20 years there's no pressure to be one thing or the other.

An interesting opinion held by fathers was a mistrust of the medical profession. These fathers wanted to be at the birth to protect both their partners and their unborn child. This opinion suggests that there is a problem with trust in late or reflexive modernity. This same point has been argued by Beck, Giddens and Lash (1994), and Bauman (2001), that as risk creates individuals who no longer accept the absolute authority of such modernist institutions. Ant's trust in an institution, such as a hospital, was severely tested by the birth of his child. He was uncomfortable, reluctant and unwilling to concede their autonomy to the medical staff during childbirth. Ant explains that he worried about his partner, their unborn child and the competence of the medical staff:

Ant: The medics turn around and say, and were basically saying, look you know what you were more worried about the well-being of your wife, or of the unborn child. And it's very difficult thing to be in, it's actually, kind of, having to weigh it up. I mean because they were... It was sort of a few minutes from caesarean, and they were doing all sorts of absolutely horrible tests on [his wife]; like doing a blood sample test 
before it was born and stuff. Which... it was difficult, because I wanted the baby to be as well treated and looked after as possible, but they were also doing stuff that was kind of hurting my wife a lot, so it was difficult.

Simon, the deputy headmaster, and Leon, the steelworker, also expressed this theme, as trust in the medical profession appeared to be increasingly put in doubt. This opinion appears to be driven by concern for their partners and their unborn children, yet also by the increasing available knowledge and understanding of the risks involved.

Simon: To support the wife, but also if anything goes wrong to put pressure on, possibly, you know the professionals. Because you know there can be a tendency to sort of let women go too far, and when it's gone too far then, you know, that's when the problems start, isn't it.

Leon: Yeah, for the supporting role and to make sure the doctors and nurses are doing their jobs properly. I spent months and months and months in hospital; the two of them were premature (pointing at photographs). She weighed $2 \mathrm{lb}$ when she was born, and she was $1 \mathrm{lb} 12 \mathrm{oz}$, I think, less than a bag of sugar the pair of them. So I could see how badly or how well the doctors or nurses are in there. So just keep an eye on things like.

Increasingly, fathers and parents in general are beginning to doubt the professionalism of expert systems. This appears to be exacerbated by the media coverage of medical mistakes and experience with dealing with such institutions. The overall feeling for these fathers was that they needed to deal with these problems on an individual basis, as collective institutions could no longer deal with individualised need. Another individualised problem was dealing with a long-term illness of a partner. This "forced" these fathers to take on greater involvement with the everyday duties of parenting. Individualised parenting appears to be driven by situational necessity and once these fathers took on more responsibility they appeared to continue even after their partners recovered.

\section{PARTNER AND CHILDHOOD ILLNESS AS A FACILITATOR IN FATHERING INVOLVEMENT}

One of the driving forces behind a father's greater involvement with their offspring is a situational one. Increasingly, parents are rearing children away from kinship support, or that support is not there for one reason or another. 
Consequently, if any problems occur with one or other of the partners, they have to either arrange expensive outside childcare or increase the involvement of the healthy partner. This is precisely the problem faced by a number of the fathers I interviewed. Over a quarter of the sample said that they increased their involvement within the family unit as a result of illness to their partner or child. Given that traditional kinship groups are breaking down, reforming, or being renegotiated it should not be a surprise that households are left to "sort out" their own problems.

This idea is not entirely new as Michael D. Young and Peter Willmott (1973) explained in their work The Symmetrical Family, although in their study, this was caused by the creation of the nuclear family stretching kinship ties. Today, however, it is not the creation of the nuclear family, which is at the centre of this change; rather it is the de-traditionalisation of the entire social structure. De-traditionalisation driven by individualisation leaves the individual alone, or with minimal negotiated help, responding to the unforeseen circumstance of late modern life. Negotiated help may take the form of kinship help, if family will/can help, or paid outside childcare. Nonetheless, a quarter of the fathers in this study responded by involving themselves as much as possible without totally relying on others. Their particular type of fathering has led to increased bonding with their children, and to a greater awareness that fathers were also parents. Phil became a father later in life, and before the birth of his daughter his wife had several miscarriages. This had the quite understandable result of Phil taking a large interest in his partner's wellbeing and that of the unborn child. After outlining the involvement in his partner's pregnancy, and how he juggled work with going to all the hospital appointments, Phil went on to describe his feelings towards his partner, child and what he thought should be modern fatherhood:

Phil: I think the role of the father has been overlooked. Everybody looks towards the mother and says yes, it's the mother who looks after the child and the mother does this, and the mother does that, and the father is getting left out on the ledge. But what I've found is that we have a traditional marriage but in a modern time, and a lot of the work is actually done by me. Or at least it's not a lot of work, we share, we share the work with the baby. I feed the baby now the baby is going onto mix feeding. I feed the baby, I change the nappies, I bath the baby, I put the baby to sleep... So there's no longer a demarcation line, it's not just the mother who looks after the baby. I think it's a duo, a partnership, and the father's part of that partnership is a very important role within the marriage and the family. 
Lewis, a student father, is another example of increased fathering involvement in the nurturing of children, due to partner's illness. Many of the fathers interviewed became involved in this way and Lewis best demonstrates this type of involvement. Lewis explains how he and his wife attempted to deal with her post-natal depression, and how they shared the nurturing of their baby.

Lewis: Well [his wife] was seriously ill, with post-natal depression for two years after baby was born. She needed her sleep and so she insisted on breast-feeding for a length. I think she breast-fed for over a year in fact, um but I would feed in the middle of the night from milk she'd saved up, and what have you, because basically I can survive on less sleep than she could.

Being "forced" into a greater nurturing role appears to help the father come to terms with being a parent. As we can detect from the comments above this turns out to be an emotionally fulfilling experience for the fathers involved, and appears to create a better bond between father and child. This should be food for thought as policy makers grapple with issues such as paternity leave. Swedish social policy enables the father to take paternity leave as part of a combined parental leave, helping fathers to bond with their young babies (Haas 1993). Making a father take the step into the domestic sphere appears to make them more aware of their parental responsibilities. On a similar line, and a constant theme amongst these fathers was the moment they realised they had a dependent. Dave exemplifies this when faced with his wife's unconscious state after the birth of their twins; it was then that he first became fully aware of the enormity of being a father.

Dave: I think I first became a father in the truest sense, when [his wife] was, after the caesarean [his wife] was anaesthetised. She had the full, she went under fully, and I was left with the babies, the twins, while [his wife] was completely asleep for hours and hours... So it was thrust upon me, and I thought immediately, these children have no one except me. At that moment with [his wife] being out of it, there was no way that I could just leave them. I could have left them with a nurse in theory, but that's not what I felt. I felt that I had to be there to protect if you like.

These fathers are attempting to build new relationships, which are free from any ascribed norms inherent in older more traditional relationships. Therefore, they do not want to be excluded from any experience, especially anything that helps them bond with the child. Becoming a friend to their children and being involved with all aspects of their children's lives was expressed by the 
majority of these fathers. Being close to and listening to one's child was taken even further by Clive, when he declared that he has a better relationship with his daughter than his wife does. He believed that his wife did not have as much patience, and his daughter comes to him for advice in all areas, even on a topic such as sex.

Clive: I am very, very close to my daughter. More close to my daughter than what my wife is. My daughter comes to me for, you know, we talk about sex, everything, you know openly, and she comes to me not her mother, because I am the type who has got common sense. I sit and listen...

The fathers confirmed that they wanted to be involved in the lives of their children. They demonstrated a better understanding of their children's needs and their own emotional expression was far better than that of their fathers. Overwhelmingly, these fathers wished to be involved with their children and showed a variety of activities in which they became involved. As with other areas in fatherhood, inclusion in the family process was dependent on decisions made by family circumstance. As fathers, these male parents benefited from creating new relationships, either by unintended circumstance or conscious choice. They had to respond to a situational need in their relationship and this appears to have given them a positive outcome in parenting skills. Rather than in some other researchers' role inadequacy model of fatherhood where fathers are incapable of nurturing and incompetent, these fathers did an adequate job and this was then incorporated into their own fathering practices.

\section{CONCLUSION}

This paper suggests that fathering is becoming very disparate and diverse. These fathers portray variations in fathering styles from the traditional to detraditional fatherhood. It also enlightens us as to how fathers negotiate spatial boundaries with their children, and appear to be building something different in their father/child relationship. It seems that although the power relationship between child and adult still obviously exists, a better relationship is increasingly about understanding each other, not the authoritarian patriarch of previous generations. Boundaries still have to be set but these boundaries are discussed and negotiated rather than dictated and demanded.

Fathering, and mothering, is no longer an entirely traditional, powerful, demanding and dominating force, good parenting has to be thought out indi- 
vidually and decisions made for the benefit of the unit as a whole. Fathers still appear to be pressurised by some social policies to be traditionally strong and a good role model, yet they are also pressurised by their own individualised relationship to be more loving and understanding towards their children. Fatherhood is becoming more and more fragmented as idealised models, seen in "simple" modernisation, are increasingly becoming obsolete or just another option in many. Individualisation is the diversifying force that creates the late modern father, tradition slowly disappears as individualised fathering takes its place.

One of the greatest perceived changes amongst this fathering group was towards being at the birth. These men, virtually all, believed that it was important for the male to express his love and emotions towards his partner and about to be born child, by "sharing" the experience of childbirth. Many of these men said that they cried at the birth and felt more emotionally attached to their children by the experience. Two of the fathers had their children over an extended period, about twenty years apart, and they felt that they missed out on this emotionally fulfilling experience with their first child. They felt that the change in policy, by health authorities, to encourage males into the delivery room was a bonus for new fathers. Sharing the experience appeared to be very popular amongst fathers, and probably for the first time triggering the understanding that they were actually fathers, long term.

Despite some of the traditional views still maintained by some fathers, such as being just a playmate and that their partners were overwhelmingly responsible for the nurturing of their children, fathers did respond well to a family crisis. It was clear that when a partner became ill the father did not look for total support from kinship groups; instead, they took over the nurturing duties and did them quite well. Concern for their partner as well as situational necessity triggered off this response. Interestingly, after their partner's recovery they still continued to be involved. Involvement, however, depended on the subjective interpretation of each individual father. Involvement was an individualised construct that ranged from playing with the children to being fully involved in all aspects of childcare. Fatherhood was therefore subject to individual preferences, structural change and the family's particular situational need.

It seems that when there was a situational change in their family circumstances, gender roles were abandoned, as it was a case of "all hands to the pumps". Therefore structural influences are very strong but not irreversible, and the agent can alter his own role as well as interact with the structure as a whole. It was evident that the dominant hegemonic masculinity is still an influence, but its influence is certainly beginning to be eroded by the eclectic 
mixture of new options available to men. Relationships between father and children are both at the same time traditional and new. Fathers in this study wanted to be involved and some were in the process of creating a new relationship between father and child, yet to encourage this further, more government policies should be created for fathering inclusion. Reflexive fathering is improving this traditional role, yet traditional fathers still exist but are increasingly in the minority and slowly disappearing.

\section{REFERENCES}

Bauman, Zygmunt 2000. Liquid Modernity. Cambridge: Polity Press.

Bauman, Zygmunt 2001. The Individualized Society. Cambridge: Polity Press.

Beck, Ulrich 1994. The Reinvention of Politics: Towards a Theory of Reflexive Modernization. In: U. Beck \& A. Giddens \& S. Lash. Reflexive Modernization: Politics, Tradition and Aesthetics in the Modern Social Order. Cambridge: Polity Press.

Beck, Ulrich 1992. Risk Society: Towards a New Modernity. London: Sage Publications.

Beck, Ulrich \& Beck-Gernsheim, Elisabeth 1995. The Normal Chaos of Love. Cambridge: Polity Press.

Beck, Ulrich \& Beck-Gernsheim, Elisabeth 2002. Individualization: Institutionalized Individualism and its Social and Political Consequences. London: Sage Publications.

Beck-Gernsheim, Elisabeth 1998. On the Way to a Post-Familial Family: From a Community of Need to Elective Affinities. Theory, Culture \& Society, Vol. 15, No. 33, pp. 53-70.

Beck, Ulrich \& Giddens, Anthony \& Lash, Scott 1994. Reflexive Modernization: Politics, Tradition and Aesthetics in the Modern Social Order. Cambridge: Polity Press.

Beynon, John 2002. Masculinities and Culture. Buckingham: Open University Press.

Bittman, Michael \& England, Paula \& Folbre, Nancy \& Sayer, Liana \& Matheson, George 2003. When Does Gender Trump Money? Bargaining and Time in Household Work. The American Journal of Sociology, Vol. 109, No. 1, pp. 186-214.

Castells, Manuel 1999. The Information Age: Economy, Society and Culture. Oxford: Wiley-Blackwell.

Cohen, Theodore F. 1993. What do Fathers Provide? Reconsidering the Economic and Nurturant Dimensions of Men as Parents. In: J. C. Hood (ed.) Men, Work, and Family. London: Sage Publications.

Connell, R. W. 1995. Masculinities. Cambridge: Polity Press.

Dermott, Esther 2003. The 'Intimate Father': Defining Paternal Involvement. Sociological Research Online, Vol. 8, No. 4. http://www.socresonline.org.uk/8/4/ dermott.html, last accessed on 1 July 2011.

Dermott, Esther 2008. Intimate Fatherhood:A Sociological Analysis. London: Routledge. Dienhart, Anna 1998. Reshaping Fatherhood: The Social Construction of Shared Parenting. London: Sage Publications. 
Doherty, William J. 1997. The Best of Times and the Worst of Times: Fathering as a Contested Arena of Academic Discourse. In: A. J. Hawkins \& D. C. Dollahite (eds.) Generative Fathering: Beyond Deficit Perspectives. London: Sage Publications.

Giddens, Anthony 1984. The Constitution of Society: Outline of the Theory of Structuration. Cambridge: Polity Press.

Giddens, Anthony 1990. The Consequences of Modernity. Cambridge: Polity Press.

Giddens, Anthony 1992. The Transformation of Intimacy: Sexuality, Love \& Eroticism in Modern Societies. Cambridge: Polity Press.

Giddens, Anthony 1998. The Third Way: The Renewal of Social Democracy. Cambridge: Polity Press.

Haas, Linda 1993. Nurturing Fathers and Working Mothers: Changing Gender Roles in Sweden. In: J. C. Hood (ed.) Men, Work, and Family. London: Sage Publications.

Hawkins, Alan J. \& Dollahite, David C. (eds.) 1997. Generative Fathering: Beyond Deficit Perspectives. London: Sage Publications.

Jamieson, Lynn 1999. Intimacy Transformed? A Critical Look at the 'Pure Relationship'. Sociology, Vol. 33, No. 3, pp 477-494.

Jamieson, Lynn \& Toynbee, Claire 1990. Shifting Patterns of Parental Control. In: H. Corr \& L. Jamieson (eds.) Politics of Everyday Life: Continuity and Change in Work and the Family. London: Macmillan Press Ltd.

Lash, Scott 1994. Reflexivity and its Doubles: Structure, Aesthetics, Community. In: U. Beck \& A. Giddens \& S. Lash. Reflexive Modernization: Politics, Tradition and Aesthetics in the Modern Social Order. Cambridge: Polity Press.

Lewis, Charlie \& O'Brien, Margaret 1987. Reassessing Fatherhood: New Observations on Fathers and the Modern Family. London: Sage Publications.

Lupton, Deborah \& Barclay, Lesley 1997. Constructing Fatherhood: Discourses and Experiences. London: Sage Publications.

Morgan, David H. J. 1996. Family Connections: An Introduction to Family Studies. Cambridge: Polity Press.

Morgan, David H. J. 1999. Gendering the Household: Some Theoretical Considerations. In: L. McKie \& S. Bowlby \& S. Gregory (eds.) Gender, Power and the Household. London: MacMillan Press.

Silva, Elizabeth Bortolaia \& Smart, Carol 1999. The New Family? London: Sage Publications.

Valentine, Gill 1999. 'Oh Please, Mum. Oh Please, Dad': Negotiating Children's Spatial Boundaries. In: L. McKie \& S. Bowlby \& S. Gregory (eds.) Gender, Power and the Household. London: MacMillan Press.

Warin, Jo \& Solomon, Yvette \& Lewis, Charlie \& Langford, Wendy 1999. Fathers, Work and Family Life. London: Family Policy Studies Centre for Joseph Rowntree Foundation.

Williams, Fiona 1998. Troubled masculinities in social policy discourses: fatherhood. In: J. Popay \& J. Hearn \& J. Edwards (eds.) Men, Gender Divisions and Welfare. London: Routledge.

Williams, Stephen 2002. Reflexive Fathering: The Individualisation of Fathering. Unpublished PHD thesis. Cardiff: University of Glamorgan. 
Williams, Stephen 2008. What is Fatherhood? Searching for the Reflexive Father. Sociology, Vol. 42, No. 3, pp. 487-502.

Williams, Stephen \& Williams, Lynda 2005. Space invaders: the negotiation of teenage boundaries through the mobile phone. The Sociological Review, Vol. 53, No. 2, pp. 314-331.

Young, Michael Dunlop \& Willmott, Peter 1973. The Symmetrical Family: A Study of Work and Leisure in the London region. London: Routledge \& Kegan Paul. 